Gulawentah: Jurnal Studi Sosial

ISSN 2528-6293 (Print); ISSN 2528-6871 (Online)

Vol. 5, No. 1, Juni 2020, Hal 17-27

Tersedia online: http://e-journal.unipma.ac.id/index.php/gulawentah

\title{
Peran Wanita Karir dalam Menanamkan Nilai-nilai Agama bagi Anak melalui Pendekatan Religius (Studi Kasus Kota Padang Sumatera Barat)
}

\author{
Y Yusutria \\ Universitas Ahmad Dahlan (UAD) Yogyakarta, Jl. Jend. Ahmad Yani, Ringroad Selatan \\ Tamanan Yogyakarta 55196, Indonesia \\ Email: yusutriayusut@ymail.com
}

Naskah diterima: 7/5/2020; Revisi: 12/5/2020; Disetujui: 21/5/2020

\begin{abstract}
Abstrak
Wanita yang membantu suami dan meringankan beban biaya keluarga dengan melakukan suatu pekerjaan yang ditekuni merupakan seorang wanita karir. Sebagai seorang wanita karir ada permasalahan yang ditimbulkan baik dalam membagi waktu untuk bekerja dan untuk rumah tangga dan terjadinya perselingkuhan. Tujuan penelitian untuk mengetahui peran wanita karir dalam menanamkan nilai-nilai agama bagi anak melalui pendekatan religius. Metode yang digunakan dalam penelitian ini adalah penelitian kualitatif dengan metode deskriptif. Teknik pengumpulan data dari observasi, kuesioner tertutup. Alat pengumpulan data berdasarkan panduan observasi dan kuesioner tertutup. Berdasarkan sumber data penelitian sebanyak 15 orang. Analisis pada penelitian adalah reduksi data, display data, pengambilan keputusan dan verifikasi yang disajikan secara deskriptif kualitatif. Pengujian keabsahan data dilakukan dengan melakukan perpanjangan pengamatan dan triangulasi sumber. Hasil penelitian yang mempengaruhi wanita karir dalam menanamkan nilai-nilai agama bagi anak pembagian waktu kerja, pola asuh anak dan pengasuhan anak, kurangnya perhatian orang tua dalam menanamkan nilai agama dan media sosial, televisi, cetak dan pengaruh lingkungan masyarakat. Peran wanita karir dalam menanamkan nilai-nilai agama bagi anak melalui pendekatan religius adalah memberikan suritauladan yang baik, memasukan anaknya kelembaga pendidikan Islam seperti MI, MTs, MA, Pesantren, PTAI. Memasukan anaknya mengaji di MDA/MDW, serta memperhatikan tingkahlaku dan kepribadian anaknya, dengan penuh kedisiplinan dalam beribadah dan dalam rumah tangga.
\end{abstract}

Kata kunci: wanita karir; pendidikan agama, pendekatan religius

\section{Role of Carrer Women in Installing Religions Values for Children Throught a Religius Approach (Case Study of Padang Sumatera Barat City)}

\begin{abstract}
The woman who helps her husband and eases the burden of family expenses by doing a job that is occupied is a career woman. As a career woman, there are problems that arise both in allocating time for work and for the household and for infidelity. The research objective is to determine the role of career women in instilling religious values for children through a religious approach. The method used in this research is qualitative research with descriptive methods. Data collection techniques from observation, a closed questionnaire. Data collection tools based on observation guidelines and a closed questionnaire. Based on research data sources as many as 15 people. The analysis in this research is data reduction, data display,
\end{abstract}

DOI: 10.25273/gulawentah.v5i1.6453

Some rights reserved. 
decision making and verification presented in a descriptive qualitative manner. Data validity testing is done by extending the observation and triangulation of sources. The results of research that affect career women in inculcating religious values for children division of work time, child care and child care, lack of parents' attention in instilling religious values and social media, television, print and the influence of the community environment. The role of career women in instilling religious values for children through a religious approach is to provide good examples, including their children in Islamic educational institutions such as MI, MTs, MA, Islamic Boarding Schools, PTAI. Entering their children to recite the MDA / MDW, and pay attention to their children's behavior and personality, with full discipline in worship and in the household.

Keywords: career woman; religious education, religious approach

\section{Pendahuluan}

Allah telah menciptakan manusia, berpasang-pasangan yang terdiri dari pria dan wanita, berbangsa-bangsa dan bersuku-suku supaya saling mengenal satu dengan yang lainnya. Sehingga bisa menjalin hubungan rumah tangga dengan jalin tali pernikahan demi mencari keridhoan Sang Illahi. Orang telah mengenal bahwa fungsi wanita ini tidak hanya dikenal sebagai 3R (kamar, sumur, dapur), sehingga wanita menuntut untuk lebih luas dengan pengaruh globalisasi dan modrenisasi, yang menjadikan wanita tersebut menuntut untut emansipasi wanita dengan menjadi wanita karir. Hal tersebut dimulai semenjak Islam, memberikan kesempatan kepada wanita untuk mengembangkan karirnya sesuai dengan minat yang dimilikinya dan disesuaikan dengan pekerjaan yang membutuhkan pendidikan (Arisandy, 2016). Pada zaman sekarang peranan wanita sangat berbeda dengan peranan wanita pada zaman dahulu. Karena wanita zaman sekarang, mengedepankan statusnya sebagai emansipasi wanita, dengan alasan bahwa manusia tersebut bisa dan mampu untuk menjalankan peran serta fungsinya sebagai makhluk sosial (Abdullah, 2013), sehingga wanita diizinkan untuk berkiprah di luar rumahnya dan bahkan sering terlibat dengan berbagai kegiatan yang ada di lingkungan masyarakat. Wanita pada saat sekarang bukan hanya sekedar membantu suami dalam rumah tangga suaminya sebagai ibu bagi anak-anaknya (melahirkan, mengasuh, mendidik dan merawat serta membesarkan anaknya) akan tetapi wanita juga memikili kesempatan untuk membantu suaminya dalam permasalahan ekonomi, mengingat kebutuhan ekonomi saat sekarang ini (Ramadhani, 2016).

Hal tersebut menjadi suatu permasalahan bagi seorang wanita sampai sekarang ini, dengan adanya pergeseran peran wanita yang tidak hanya terbatas pada rumah tangga suaminya, melainkan jua pada kehidupan modren (Muhammadun, 2015). Adanya upaya yang dilakukan oleh seorang wanita dalam meningkatkan status sosial khususnya dalam ekonomi keluarganya, yaitu dengan menjadi wanita karir atau mencari kegiatan yang positif sehingga dapat membantu perkonomian yang ada dalam rumah tangga suaminya. Dengan demikian wanita tersebut memiliki peran ganda yaitu berperan secara domestik yaitu wanita yang berperan sebagai istri bagi suaminya, sebagai ibu bagi anaknya, sebagai pengelola rumah tangga. Adapun peran selanjutnya adalah peran publik, yaitu wanita sebagai tenaga kerja yang turut aktif dalam kegiatan ekonomis yang disesuaikan dengan keterampilan dan pendidikan yang ada di lapangan pekerjaan yang tersedia (Triana \& Krisnani, 2018).

Sehingga wanita karir memilki memainkan peran yang ganda, yang menjadikan seorang wanita tidak mudah menyelesaikan permasalahan yang dihadapinya, karena wanita tersebut dituntut dan diminta untuk memainkan peran keduanya dengan hasil yang sama baiknya, jika wanita tersebut lebih memprioritaskan pekerjaan yang dilakukannya, sehingga dapat mengorbankan banyak hal untuk keluarganya. Keseimbangan kerja, kehidupan diperlukan agar seseorang dapat menyeimbangkan antara waktu ditempat kerja dan aktivitas lain diluar kerja termasuk keluarga dan kehidupan pribadinya (Mayangsari \& Amalia, 2018). 
Pada hakekatnya wanita karir membawa pengaruh yang positif dalam meringankan beban dan tanggungjawab yang dihadapi oleh suaminya terutama dalam masalah kebutuhan ekonomi keluarga, secara langsung dapat menambah penghasilan keluarga. Selanjutnya berdampak pada kurangnya perhatian dan kasih sayang kepada keluarga dan anak-anaknya, disebabkan banyaknya waktu yang tersita oleh pekerjaan yang ditekuninya di luar rumah. Karena dalam hubungan keluarga, antara suami dan istri dituntut adanya hubungan yang baik dalam suasana yang harmonis demi terciptanya kehidupan beragama yangkuat, suasana yang hangat, saling harga menghargai, saling pengertian, keterbukaan, menjaga harkat dan martabat tentunya dengan penuh rasa kasih sayang didasari adanya rasa saling kepercayaan yang tumbuh dan berkembang (Djunaedi, 2018).

Memperhatikan masalah yang dihadapi oleh seorang wanita karir, yang bekerja secara rutin tiap hari mulai dari pagi dan pulang pada sore hari, bahkan ada yang pulang sampai malam, baik ada diantara wanita karir tersebut ada yang bekerja di dalam kota maupun di luar kota tempat yang jauh dari tempat domisili, sehingga mengakibatkan sedikitnya memiliki waktu dalam mengurusi rumah tangga terutama dalam mengasuh, mendidik anaknya, khususnya dalam menanamkan nilai-nilai agama. Wanita yang memainkan perannya secara ganda, menjadikan wanita tersebut akan menghadapi berbagai permasalahan baik permasalahan dalam mengembangkan karirnya sebagai wanita yang bekerja dan juga dalam keluarganya khususnya dalam mendidik anaknya. Berdasarkan permasalahan tersebut penulis membahasnya dalam suatu pembahasan tentang peran wanita karir dalam menanamkan nilai-nilai agama bagi anak melalui pendekatan religius (studi kasus Kelurahan Surau Gadang kecamatan Nanggalo kota Padang Sumatera Barat). Urgensi penelitian ini bertujuan untuk mengungkapkan tentang tentang peran wanita karir dalam menanamkan nilai-nilai agama bagi anak melalui pendekatan religius. Sehingga penelitian ini diharapkan dapat memberikan kontribusi terhadap peran dan pola wanita karir dalam menanamkan nilai-nilai agama bagi anak melalui pendekatan religius. Secara praktis penelitian ini dapat memberikan tambahan ilmu bagi seorang wanita tentang pola dan metode yang digunakan oleh wanita karir dalam menanamkan nilai-nilai agama bagi anak melalui pendekatan religius.

Adapun ada beberapa penelitian yang memperkuat penelitian tentang wanita karir, diantaranya penelitian yang dilakukan oleh (Djunaedi, 2018), tentang peran ganda perempuan dalam keharmonisan rumahtangga. Selanjutnya poeses pengasuhan ibu bekerja sebagai tani, guru dan pedagang, tentang perencanaan pengasuhan yang dilakukan oleh seorang ibu pekerja (Adi Wibowo \& Satih Saidiyah, 2013). Penelitian yang membahas tentang adanya bahaya konflik yang ditimbulkan oleh wanita yang memiliki peran ganda sebagai wanita karir dalam pandangan agama Islam. Namun dari beberapa penelitian tersebut belum ditemukan pembahasan yang spesifik tentang kontirbusi wanita karir dalam menanamkan nilai-nilai agama bagi anak melalui pendekatan religius.

Berdasarkan latar belakang tersebut dapat dipahami bahwa permasalahan yang dihadapi wanita karir, yang bekerja secara rutin tiap hari mulai dari pagi dan pulang pada sore hari, bahkan ada yang pulang sampai malam, baik ada diantara wanita karir tersebut ada yang bekerja di dalam kota maupun di luar kota tempat yang jauh dari tempat domisili, sehingga mengakibatkan sedikitnya memiliki waktu dalam mengurusi rumah tangga terutama dalam mengasuh, mendidik anaknya, khususnya dalam menanamkan nilai-nilai agama. Wanita yang memainkan perannya secara ganda, menjadikan wanita tersebut akan menghadapi berbagai permasalahan baik permasalahan dalam mengembangkan karirnya sebagai wanita yang bekerja dan juga dalam keluarganya khususnya dalam mendidik anaknya.

Berdasarkan permasalahan tersebut penulis membahasnya dalam suatu pembahasan tentang peran wanita karir dalam menanamkan nilai-nilai agama bagi anak melalui pendekatan religius (studi kasus Kelurahan Surau Gadang kecamatan Nanggalo kota Padang Sumatera Barat). Adapun tujuan dari penelitian adalah untuk mengetahui faktor yang mempengaruhi peran wanita karir dalam menanamkan nilai-nilai agama bagi anak melalui pendekatan religius 
(studi kasus Kelurahan Surau Gadang kecamatan Nanggalo kota Padang Sumatera Barat) dan untuk mengetahui peran wanita karir dalam menanamkan nilai-nilai agama bagi anak melalui pendekatan religius (studi kasus Kelurahan Surau Gadang kecamatan Nanggalo kota Padang Sumatera Barat).

\section{Metode Penelitian}

Jenis penelitian yang dipakai dalam penelitian ini adalah penelitian kualitatif dengan metode deskriptif untuk mendeskripsikan berdasarkan dengan realita dan fakta-fakta yang ada di lapangan terkaik dengan wanita karir dalam menanamkan nilai-nilai agama bagi anak melalui pendekatan religius (studi kasus kota Padang Sumatera Barat).

Penelitian ini dilakukan pada bulan September sampai bulan Oktober 2019, dengan lokasi penelitian di RT/RW. 01/III kelurahan Surau Gadang kecamatan Nanggalo kota Padang Sumatera Barat. Hal tersebut berdasarkan dengan banyaknya wanita yang memiliki peran sebagai wanita karir. Teknik pengumpulan data dari observasi, kuesioner tertutup. Alat pengumpulan data berdasarkan panduan observasi dan kuesioner tertutup. Berdasarkan sumber data penelitian sebanyak 15 orang. Analisis pada penelitian adalah reduksi data, display data, pengambilan keputusan dan verifikasi yang disajikan secara deskriptif kualitatif. Pengujian keabsahan data dilakukan dengan melakukan perpanjangan pengamatan dan triangulasi sumber. Teknik analisis data berasal dari data angket yang telah dikumpulkan dihitung persentasenya jawaban dari responden yang telah menjawab dan yang telah mengumpulkan, kemudian dihitung per item jawabannya, selanjutnya dilakukan penganalisisan dengan cara deskriptif kualitatif dengan menggunakan beberapa tahap, baik dengan cara mereduksi data, penyajian data dan penarikan kesimpulan/verifikasi data. Triangulasi teknik dan sumber peneliti gunakan dalam rangka menguji keabsahan data.

\section{Hasil dan Pembahasan}

1. Faktor yang mempengaruhi wanita karir dalam menanamkan nilai-nilai agama bagi anak melalui pendekatan religious.

Secara deskriptif faktor-faktor yang mempengaruhi wanita karir dalam menanamkan nilai-nilai agama ditampilkan dalam beberapa grafik. Pada gambar 1 disampaikan data terkait dengan jenis pekerjaan yang ditekuni oleh sampel penelitian.

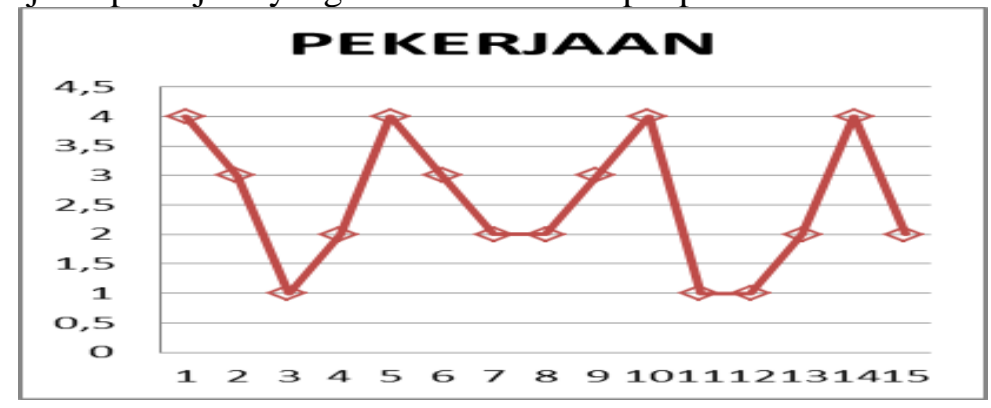

Gambar 1. Jenis Pekerjaan

Berdasarkan gambar 1 tersebut dapat dipahami bahwa sebanyak 4 orang statusnya sebagai pegawai negeri sipil (PNS) dan 3 orang menekuni sebagai pedagang, sebanyak 5 orang pekerjaan sebagai pegawai swasta, sebanyak 3 orang yang statusnya sebagai ibu rumah tangga.

Ditinjau dari pekerjaan yang ditekuni oleh seorang wanita adalah lebah banyak yang menekuni sebagai pegawai swasta dan banyak yang menekuni sebagai PNS dan cukup yang menekuni sebagai pedagang dan ibu rumah tangga. Hal tersebut sebut sesuai dengan 
pemahaman tentang wanita karir yang merupakan suatu karya yang sulit dipisahkan dengan kehidupan manusia, yang memberikan harapan kebahagian untuk masa depan yang cerah dalam kehidupan sebagai manusia. Sehingga panggilan tersebut tidak membedakan jenis kelamin untuk berkarya. Jika memahami tentang wanita karir adalah seorang wanita yang mempunyai minat untuk mendalami suatu pekerjaan yang ditekuninya untuk meraih prestasi yang baik dan kedudukan yang bagus serta gaji yang sesuai dengan profesionalitasnya yang membutuhkan waktu panjang untuk meraih masa depan yang cemerlang tersebut (Arisandy, 2016).

Sehingga seorang wanita yang ingin berkarir mengemukakan alasanya untuk menjadi wanita karir. Pertama; alasan jenjang pendidikan yang telah diraih dan diperolehnya, sehingga wanita tersebut ingin membuktikan bahwa wanita tersebut mampu bersaing dengan laki-laki untuk mendapatkan kesempatan pekerjaan yang baik dan mapan. Kedua; mengedepankan status sosial dalam pengembangan diri yang disesuaikan dengan minat dan bakat yang dimilikinya, serta ketiga adalah berdasarkan kebutuan ekonomi yang dirasakan, sehigga ada tuntutan untuk memperoleh kehidupan yang layak berdasarkan ekonomi (Pravitasari et al., 2019). Wanita yang memiliki kemampuan untuk memajukan dan mengembangkan potensi yang ada dalam dirinya ke arah positif baik dalam kehidupan maupun pekerjaan yang ditekuninya, serta memiliki tanggungjawab yang besar dalam dirinya, keluarga dan masyarakat, tentunya menjaga baik aturan yang berlaku, wanita yang demikian bisa dikatakan dengan wanita karir.

Selanjutnya alasan seotang wanita karir, dapat dilihat pada gambar 2.

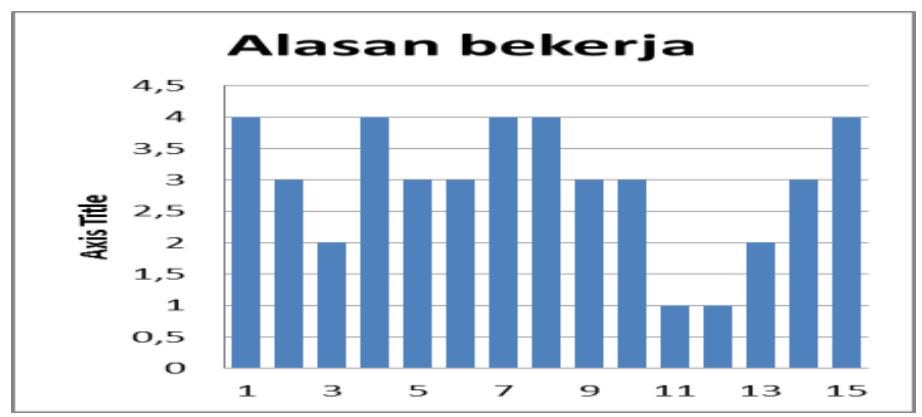

Gambar 2. Alasan Bekerja

Berdasarkan gambar 2 tersebut dapat dipahami bahwa alasan wanita menekuni menjadi wanita karir adalah sebanyak 5 orang dengan alasan ingin membantu suaminya, adapun dengan tujuan untuk meningkatkan status sosial rumah tangganya sebanyak 6 orang, dan sebanyak 2 orang mengemukakan alasan menjadi wanita karir adalah sebagai penghasilan utama, serta sebanyak 2 orang dengan tidak mengemukakan alasan. Permasalahan yang dihadapi wanita karir dalam mengasuh dan pola asuh yang akan diterapkannya dalam mengasuh dan mendidik anaknya untuk terciptkanya nilai-nilai ajaran agama yang baik bagi anak.

Adapun alasan wanita menekuni menjadi wanita karir, lebih banyak mengedepankan alasan untuk meningkatkan status sosial dalam keluarga sehingga berdampak pada status sosial dalam masyarakat, selanjutnya banyak diantara wanita karir yang mengedepankan alasan untuk membantu ekonomi rumah tangga atau ingin membantu suami dalam meringankan beban suami, dan cukup diantara wanita karir yang mengemukan alasannya menjadi wanita karir adalah sebagai penghasilan tetap dan tidak mengemukakan alasan yang jelas.

Adanya lebih banyak wanita karir yang mengedepankan alasan untuk meningkatkan status sosial dalam keluarga sehingga berdampak pada status sosial dalam masyarakat, hal 
tersebut tidak bisa dipungkiri dan tidak heran lagi bahwa tatanan dan tindakan serta prilaku seseorang sudah terjadi pergeseran sesuai dengan perubahan dan tuntutan gaya hidup masyarakat Indonesia, yang mengarah kepada budaya barat, fashion, cara berkomunikasi, cara berinteraksi. Gaya inilah yang menganut ke arah modrenisai yang teraktualisasi dalam tingkahlaku dan perbuatan seseorang (Lamopia \& Wulandari, 2017).

Banyak juga diantara wanita karir yang mengedepankan alasan untuk membantu ekonomi rumah tangga atau ingin membantu suami dalam meringankan beban suami. Statusnya sebagai wanita karir memiliki beberapa keuntungan yang diperolehnya, baik; keuntungan dari segi ekonomi, sehingga wanita terebut dapat membantu nafkah keluarganya dan meningkatkan serta menunjang kesejahteraan keluarganya.

Keuntungan dari segi sosialisasi dalam mengenal lingkungan sekitar dan lingkungan tempat kerja. Selanjutnya adalah keuntungan afeksi, yang merupakan suatu prilaku didikembangkan berdasarkan pada lingkungan sosial dan sikap yang ada dalam dirinya. Adapun keuntungan yang lainnya adalah keuntungan agama, sebagai seorang yang wanita karir, wanita tersebut bekerja disamping untuk keuntungan ekonomi juga untuk mencari keridhoaan dari Allah SWT (Lailiyah \& Ridlwan, 2020).

Adanya keinginan dalam diri seorang wanita yang sedang meniti karir adalah keinginannya tidak jauh berbeda yaitu untuk meningkatkan status sosial ekonomi dan kemakmuran, yang semuanya agar terhindar dari kemiskinan, sehingga wanita dan kelurganya bisa berperan demi membantu dirinya dan demi orang yang dicintainya serta terpenuhinya kebutuhan keluarganya dengan cara yang halal lagi baik dan berkah.

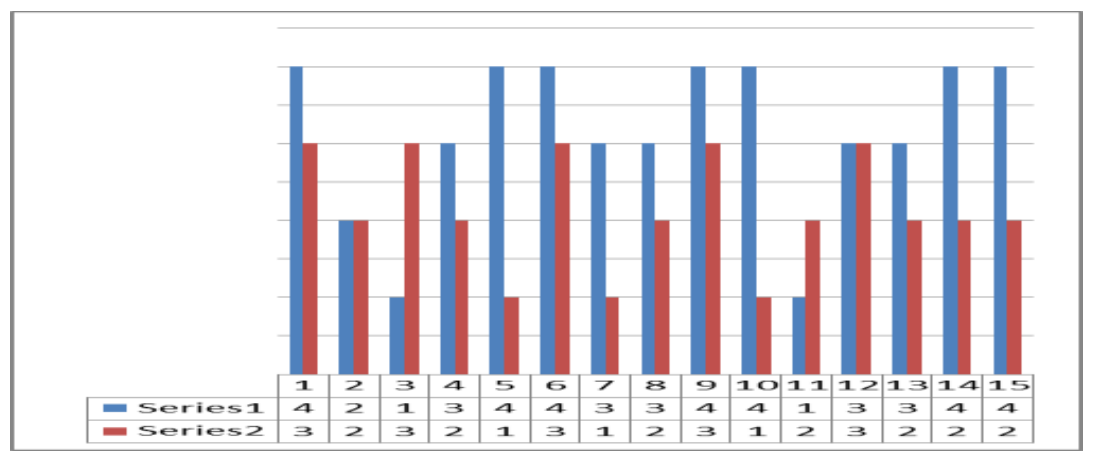

Gambar 3. Pengertian Pola Asuh Anak

Berdasarkan gambar 3 dapat pahami bahwa sebanyak 7 orang yang menitipkan anaknya pada orang tuanya maupun pada mertua jika sedang pergi bekerja, sebanyak 5 orang menitipkan anaknya pada seorang pengasuh untuk mengasuh anaknya jika sedang pergi ketempat kerja. Selanjutnya sebanyak 1 orang yang membawa anak ketempat kerja dan sebanyak 2 orang memilih lain-lain dengan alasan saling bergantian. Adapun pola asuh dalam pengasuhan anak adalah sebanyak 5 orang yang mengedepankan dengan cara demokrasi dalam cara mengasuh dan mendidik anaknya, sebanyak 7 orang yang permisif dalam mengasuh dan mengarahkan anak didiknya, serta sebanyak 3 orang membiarkan apa yang diperbuat dan dilakukan oleh anaknya.

Sebagai wanita karir, jika wanita tersebut pergi bekerja yang mengasuh anaknya adalah; wanita tersebut lebih banyak menitipkan anaknya pada orang tuanya maupun kepada mertuanya. Banyak juga dari wanita karir tersebut yang menitipkan anaknya pada seorang pengasuh untuk mengasuh anaknya saat pergi ketempat kerja. Cukup dari wanita karir yang mempercakan pengasuh anaknya saling bergantian dengan melihat situasi dan kondisi dalam artian tidak menetap dan rendah dari wanita karir yang membawa anak 
ketempat kerja, jika pergi ke tempat kerja dengan alasan nanti mengganggu pekerjaan dan ketidak nyamanan dalam bekerja. Sebagai seorang wanita karir, tentunya akan menghadapi permasalahan baik di lingkungan keluarga maupun dilingkungan tempat kerja, diantaranya adalaha: pertama; permasalahan dalam pengasuhan anak, sebagai wanita karir waktunya kurang dalam mengasuh, mengurus, mendidik, menajaga anak agar tumbuh berkembang secara fisik dan psikis. Sehingga waktunya kerap digantikan oleh orang lain seperti pembantu rumahtangga sekaligus mengasuh anaknya, menitipkan anaknya di rumah titipan.

Kedua; permasalahan dalam pekerjaan rumahtangga. Mengingat wanita karir, waktunya lebih dominan di luar sehingga perhatiannya untuk membersihkan rumah, membantu suaminya dalam menyiapkan segala sesuatu yang berkaitan dengan rumah tangga kerika berada dalam rumah. Kadangkalanya dibantu oleh seorang pembantu rumah tangga. Ketiga; permasalahan pada minimnya interaksi dalam rumah tangga dan tentang lingkungan sekitar. Kekurangan akan komunikasi dalam rumah tangga dan dengan masyarakat sekitarnya juga merupakan dampak dari seorang wanita sebagai wanita karir (Ermawati, 2016).

Sebagai seorang wanita karir memainkan peran ganda baik sebagai ibu dalam rumah tangga, seorang ibu bagi anak-anak yang akan mendidik dan mengasuh anak-anaknya, dan seorang wanita yang mengejar karirnya. Pengasuhan anak yang dilakukan oleh seorang wanita terhadap anak-anaknya ada beberapa tipe, diantaranya adalah: pertama; pola asuh secara otoriter, merupakan pola asuh yang menuntut kepada seorang anak untuk hidup lebih mandiri, akan tetapi seluruh aturan dan kedisiplinan yang suatu sikap yang menunjukan perilaku untuk taat dan tunduk pada atura yang telah ditetapkan seta wajib diterapkan, dijalankan oleh seorang anak berdasarkan kehendak dari orangtuanya dan sebagai anak harus mengikutinya.

Kedua; pola asuh secara demokratis, yang menghargai seluruh tingkahlaku, perbuatan yang dilakukan oleh anaknya berdasarkan pertimbangan secara rasional, dan membangun komunikasi yang baik antara anak dengan orangtua. Ketiga; pola asuh secara permisif. Pada pola asuh ini orang tua berperan sangat sedikit dari dalam membentuk kemandirian pada anaknya, sehingga peran anak lebih dominan untuk menentukan masa depannya, aktivitasnya dengan tanpa diawasi oleh orangtuanya untuk mencapai tujuan yang dinginkan oleh anak (Muryanti, 2020).

Selama wanita karir tersebut tidak keluar dari aturanya yang telah disepakati dalam rumah tangganya dan aturan agama serta aturan yang ada dalam masyarakat, wanita tersebut dizinkan untuk meniti karir. Jika wanita tersebut melanggar aturan yang telah disepakati akan berdampak pada pemasalahan baik pada dirinya, keluarga, lingkungan masyarakat serta agama. Seorang wanita hendaknya memilih pekerjaan yang cocok dengan kodratnya sebagai wanita, yang dapat menjaga kehormatan diri, keluarga, masyarakat dan agamanya. 


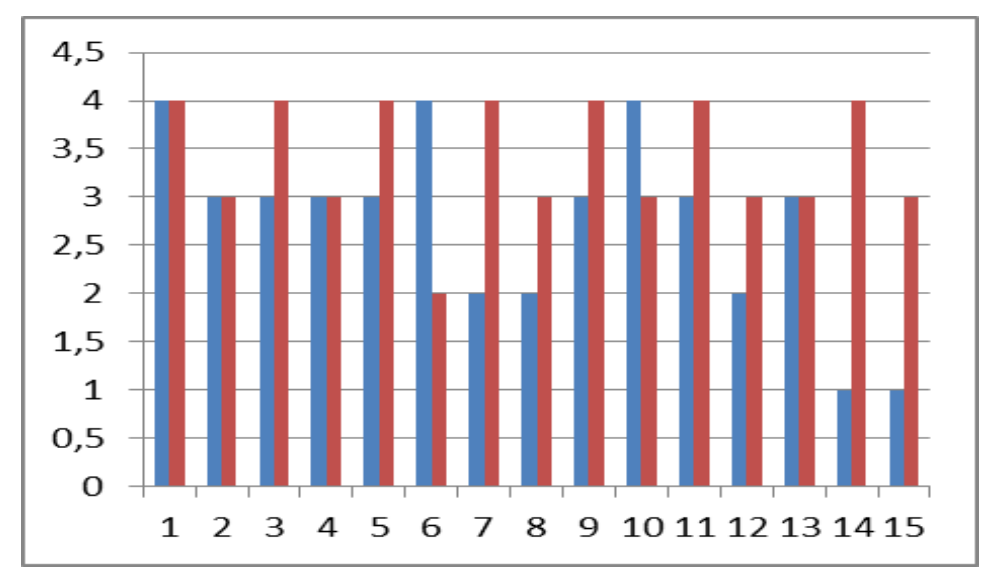

Gambar 4. Kendala yang dihadapi

Berdasarkan gambar 4 di atas kendala internal yang dihadapi oleh wanita karir dalam menanamkan nilai-nilai agama adalah bersumber dari media telivisi sebanyak 3 orang, yang bersumber dari media sosial sebanyak 7 orang, yang bersumber dari lingkungan masyarakat, sebanyak 3 orang dan sebanyak 2 orang bersumber dari media cetak. Untuk mengetahui permasalahan yang ditimbulkan dari seorang wanita karir. Sementara kendala yang berasal dari eksternal wanita karir dalam menanamkan nilai-nilai agama adalah sebanyak 7 orang mengedepankan alasan karena kelelahan bekerja, sebanyak 7 orang dengan banyak wanita yang mengedepankan alasan karena kesibukan di kantor atau tempat bekerja dan sebanayk 1 orang karena kurang pemahaman dalam ajaran agama.

Kendala yang dihadapi oleh wanita karir dalam menanamkan nilai-nilai agama secara internal adalah lebih banyak yang bersumber dari media sosial yang berasal dari WA/Facebook/Messenger/Instagram, banyak juga berasal dari media telivisi dan lingkungan masyarakat sekitarnya dan cukup dari media cetak. Adapun kendala yang berasal dari eksternal wanita karir dalam menanamkan nilai-nilai agama, sangat banyak dari wanita karir yang menjawab bahwa faktor luarnya karena kelelahan kembali dari tempat bekerja dan kesibukan ketika bekerja, cukup dari wanita karir yang menjawab dengan alasan kurang pemahaman akan ajaran agama.

Kendala yang dirasakan oleh wanita karir baik yang berasal dari internal maupun eksternal, maka ada beberap solusi yang perlu diingat dan diperhatikan oleh seorang wanita karir dalam menghadapi permasalahan-perlasalahan yang dihadapi dalam menanamkan nilai-nilai agama bagi anak melalui pendekatan religius adalah mencari keridhoan dari suami tentunya memperoleh izin dari sang suami. Seorang wanita tersebut mampu menjaga dirinya dari laki-laki tempat wanita tersebut bekerja tentunya tujuannya adalah untuk menghindari terjadinya fitnah. Sebagai seorang wanita hendak memperhatikan cara berkapaiannya dan hendaknya menutup aurat dengan mengedepankan berakhlaqul karimah, sehingga tidak diganggu oleh laki-laki lain. Selanjutnya sebagai seorang wanita, alangkah baiknya wanita tersebut memilih tempat pekerjaan yang cocok dengan keilmuannya, kodratnya sebagai wanita dan tentunya tidak melupakan nilai-nilai agama yang ada dalam dirinya.

Hal tersebut sesuai bahwa tugas seorang istri sebagai penerus keturunan dan pendidik adalah melahirkan anak yang sehat, normal, dan cerdas. Memiliki pengetahuan tentang pengasuhan anak dan kesehatan ibu dalam masa kehamilan dan kelahiran, serta seorang ibu memberikan rasa aman dan kasih sayang terhadap anaknya, dan adanya sikap dan pandangan yang sama antara sitri dan suami dalam mendidik anak-anaknya, agar dapat tumbuh menjaid seorang manusia yang memiliki kepribadian yang luhur, sikap watak dan 
tingkahlaku yang sesuai dengan norma yang ada dalam lingkungan keluarga dan masyarakat serta berbangsa dan bernegara (Yuliati, 2019). Sebagai wanita karir ada beberapa faktor yang akan mempengaruhinya dalam berkarir baik dari faktor internal berupa memiliki perasaan bersalah dalam dirinya, memainkan peran ganda dan ketakutan yang ada dalam dirinya berupa kendala dan hambatan untuk meraih kesuksesan, sementara faktor eksternalnya dukungan dari pihak keluarga juga mempengaruhi karirnya dan lingkungan tempat kerja dimana wanita tersebut bekerja dan berkarir (Sunarsih et al., 2018).

2. Adapun peran wanita karir dalam menanamkan nilai-nilai agama bagi anak melalui pendekatan religius.

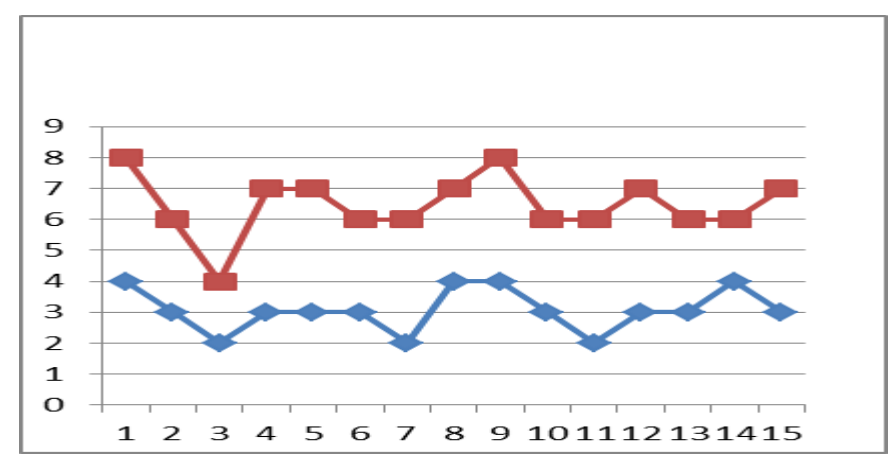

Gambar 5. Penanaman nilai-nilai agama pendekatan religius

Berdasarkan hasil gambar 5 dapat dipahami bahwa peran wanita karir dalam menanamkan nilai-nilai agama bagi anak melalui pendekatan religius adalah sebanyak 2 orang menyerahkan anaknya ke Taman Pendidikan al-Qur'an (TPA), sebanyak 5 orang menyerahkan anaknya kesekolah agama dan sebanyak 7 orang yang menyerahkan dan memasukan anaknya ke pesantren, serta 1 orang menyerahkan kepada anaknya. Adapun pendekatan secara religius yang digunakan oleh orang tua dalam menanamkan nilai-nilai agama kepada anaknya dengan cara; sebanyak 4 orang memberikan contoh atau suritauladan kepada anaknya, sebanyak 8 orang dengan mengatur kedisiplinan anaknya dalam beribadah, dan sebanyak 3 orang menyerahkan anaknya kelembaga pendidikan agama untuk memahami nilai-nilai agama bagi anaknya. Hal tersebut sesuai dengan observasi yang penliti lakukan bahwa untuk mendukung pendidikan agama, wanita karir tersebut memasukan anaknya mengaji ke masjid/MDA dan menyekolahkan ke lembaga pendidikan Islam seperti TKA/Taman Kanak-kanak Al-Qur'an, dan SDIT/Sekolah Dasar Islam Terpadu, memberikan dan menanamkan suritauladan kepada anak-anaknya kapanpun dan dimanapu, dengan menanamkan nilai kejujuran, berpakaian yang Islami, sholat berjamaah.

Berdasarkan hasil penelitian di atas dapat dibahas bahwa lebih banyak dari wanita karir yang menyerahkan dan memasukan anaknya ke pesantren,dan banyak dari wanita karir yang mempercayakan dan memasukan anaknya ke sekolah yang berbasis agama, dan tinggi dari wanita karir yang menyerahkan anaknya ke Taman Pendidikan al-Qur'an (TPA), serta cukup dari wanita karir yang memberikan kebebasan kepada anaknya dalam menentukan pilihan untuk memahami agama. Adapun lebih banyak dari wanita karir yang menanamkan kedisiplinan anaknya dalam beribadah hal ini terbukti sebanyak 8 orang dan banyak dari wanita karir pendekatan religius yang dilakukan dengan memberikan contoh atau suritauladan kepada anaknya, hal tersebut bisa dilihat dari 5 orang yang menjawab, 
sangat rendah dari wanita karir yang menyerahkan anaknya kelembaga pendidikan agama untuk memahami nilai-nilai agama bagi anaknya yaitu sebanyak 3 orang.

Walaupun sebagai wanita karir, status dirinya sebagai ibu dalam rumah tangga suaminya akan tetap melekat pada dirinya dalam keluerga. Perlu dipahami secara umum bahwa keluarga itu berfungsi; pertama; untuk menanamkan nilai-nilai agama dengan mengajarkan ajaran agama yang akan menjadi dasar dan tujuan hidup bagi seluruh anggota keluarga untuk menjalankan norma-norma yang ada dalam keluarga. Kedua; menerapkan nilai-nilai ajaran agama dalam realita kehidupan sehari-hari kepada setiap seluruh anggota keluarga. Ketiga; menginplementasikan serta mengaplikasikan nilai-nilai ajaran agama secara kongkrit dalam realita kehidupan sehari-hari.

Keempat; jika ajaran agama, pemahaman tentang agama kurang didapatkan dari sekolah maka lingkungan keluarga berperan besar dalam menanamkan ajaran agama tersebut. Karena pondasi untuk menuju keluarga kecil yang bahagia dan sejahtera berangkat dari cara membina rasa, sikap, dan praktek dalam kehidupan beragama di dalam keluarga. Hal tersebut sesuai dengan fungsi keluarga disamping juga dilihat dari sudut fungsi sosial budaya, sudut fungsi perlindungan, sudut fungsi reproduksi, dari sudut fungsi cinta kasih, dari sudut fungsi sosialisasi dan pendidikan, dari sudut fungsi ekonomi dan pemeliharaan lingkungan, dan yang tak kalah penting adalah dari sudut fungsi keagamaan, semuanya itu tertuang dalam Undang-undang No. 10 Tahun 1992 dan PP No. 21 tahun 1994 (Marlina Telaumbanua \& Nugraheni, 2018).

Hal tersebut dilakukan dengan tujuan untuk mendidik anak agar mampu menyesuaikan dirinya di lingkungan masyarakat sosial sehingga anak tersebut dapat diterima dengan baik, menjadikan anak tersebut disiplin sehingga anak tersebut mampu membedakan perbuatan dan tingkahlaku yang baik/buruk, tentunya berdasarkan dengan ketentuan yang telah disepakati dan ketentuan yang telah ada (Pravitasari et al., 2019).

Sehingga keluarga memiliki peran dan fungsi dalam semua kehidupan, baik individu, sosial maupun masyarakat banyak. Terutama fungsinya dalam meningkatkan dan menjaga akan keberlansungan, kemakmuran, kesejahteraan keluarga, tentunya menjaga dirinya, keluarganya, lingkungan masyarakatnya dari dampak pengaruh negatif.sebagai keluarga juga tentunya memperhatikan pendidikan anak dan keturunannya terutama pendidikan agama anaknya, yang akan diterapkan dalam realita kehidupan sehari-hari.

\section{Simpulan}

Peran wanita karir dalam menanamkan nilai-nilai agama bagi anak melalui pendekatan religius dipengaruhinya oleh pembagian waktu sebagai seorang wanita karir dan istri dalam rumahtangga serta ibu bagi anak-anaknya sehingga waktu yang dimiliki ibu dalam mengurus dan mendidik anak akan berkurang, dan dalam banyak kasus peran ibu kerap digantikan oleh orang lain alias pembantu. Sehingga kasih sayang ibu terhadap anak berkurang apalagi menanamkan nilai-nilai pendidikan agama bagi anak. Peran wanita karir dalam menanamkan nilai-nilai pendidikan agama bagi anaknya dengan suri tauladan dan melalui pendidikan formal dan pendidikan informal. Peran wanita karir dalam menanamkan nilai-nilai agama bagi anak melalui pendekatan religius adalah dengan memberikan suritauladan yang baik, memasukan anaknya kesekolah yang berbasiskan agama baik di MI, MTs, MA, Pesantren, PTAI. Memasukan anaknya mengaji di MDA/MDW, serta memperhatikan tingkahlaku dan kepribadian anaknya, dengan penuh kedisiplinan dalam beribadah dan dalam rumah tangga.

\section{Daftar Pustaka}

Abdullah, S. (2013). Pembangunan Gender dan Benturan Tradisi. SOCIUS, XIII(1), 22-38.

Adi Wibowo, \& Satih Saidiyah. (2013). Proses Pengasuhan Ibu Bekerja. Jurnal Psikologi Integratif, 1(2), 105-123. https://doi.org/https://doi.org/10.14421/jpsi.2013.\%25x 
Arisandy, N. (2016). Pendidikan dan Karir Perempuan dalam Prespektif Islam. Marwah: Jurnal Perempuan, Agama Dan Jender, 15(2), 125. https://doi.org/10.24014/marwah.v15i2.2643

Djunaedi. (2018). Peran Ganda Perempuan Dalam Keharmonisan Rumahtangga. Jurnal Administrare: Jurnal Pemikiran Ilmiah Dan Pendidikan Administrasi Perkantoran, 5(1), 19-26. https://doi.org/https://doi.org/10.26858/ja.v5i1.6492

Ermawati, S. (2016). Peran Ganda Wanita Karier (Konflik Peran Ganda Wanita Karier ditinjau dalam Prespektif Islam). JURNAL EDUTAMA, 2(2), 59-69. https://doi.org/http://dx.doi.org/10.30734/jpe.v2i2.24

Lailiyah, I., \& Ridlwan, B. (2020). Peran Wanita Karir Dalam Pendidikan Islam. AL-MISBAH (Jurnal Islamic Studies), 8(2), 74. https://doi.org/10.26555/almisbah.v8i2.1151

Lamopia, I. W. G., \& Wulandari, R. (2017). Komodifikasi Tubuh Perempuan Operator SPBU $\begin{array}{llll}\text { 54.801.50. Gulawentah:Jurnal Studi Sosial, } & \text { 2(2), } & 91 .\end{array}$ https://doi.org/10.25273/gulawentah.v2i2.1896

Marlina Telaumbanua, M., \& Nugraheni, M. (2018). Peran Ibu Rumah Tangga dalam Meningkatkan Kesejahteraan Keluarga. Sosio Informa, 4(2), 418-436. https://doi.org/10.33007/inf.v4i2.1474

Mayangsari, M. D., \& Amalia, D. (2018). Keseimbangan Kerja-Kehidupan pada Wanita Karir. Jurnal Ecopsy, 5(1), 43. https://doi.org/10.20527/ecopsy.v5i1.4884

Muhammadun, M. (2015). Fiqh dan Permasalahan Perempuan Kontemporer. Jurnal AlMaiyyah, 8(1), 99-119.

Muryanti, E. (2020). Pola Pengasuhan Orangtua dalam Membentuk Kemandirian Anak Usia 4-6 Tahun di Jorong Katimahar Kabupaten Pasaman Barat. SELING: Jurnal Program Studi PGRA, 6(1). https://doi.org/https://doi.org/10.29062/seling.v6i1.558

Pravitasari, A. E., Sukidin, S., \& Suharso, P. (2019). Pola Pengasuhan dan Internalisasi Nilai Kemandirian Anak pada Wanita Karir di Desa Tembokrejo Kecamatan Gumukmas Kabupaten Jember. JURNAL PENDIDIKAN EKONOMI: Jurnal Ilmiah Ilmu Pendidikan, Ilmu Ekonomi Dan Ilmu Sosial, 13(1), 78. https://doi.org/10.19184/jpe.v13i1.10424

Ramadhani, N. (2016). Implikasi Peran Ganda Perempuan dalam Kehidupan Keluarga dan Lingkungan Masyarakat. SOSIETAS, 6(2). https://doi.org/10.17509/sosietas.v6i2.4245

Sunarsih, S., Zain, D., \& Umar, I. (2018). Analisis Faktor-Faktor yang Mempengatuhi Wanita Karier dalam Pola Asuh Pendidikan Anak di Kota Pontianak. Inovbiz: Jurnal Inovasi Bisnis, 6(1), 43. https://doi.org/10.35314/inovbiz.v6i1.394

Triana, A., \& Krisnani, H. (2018). Peran Ganda Ibu Rumah Tangga Pekerja K3L UNPAD dalam Rangka Menunjang Perekonomian Keluarga. Prosiding Penelitian Dan Pengabdian Kepada Masyarakat, 5(2), 188. https://doi.org/10.24198/jppm.v5i2.18370

Yuliati, U. (2019). Analisis Peran Ganda Wanita sebagai Pekerja Paruh Waktu pada Masyarakat Pedesaan di Kecamatan Junrejo Kota Batu. Jurnal Perempuan Dan Anak (JPA), 2(2), 2334. 